\title{
EFEKTIVITAS PELAKSANAAN PILKADA SERENTAK 2020 PADA MASA PANDEMI DARURAT COVID-19 DI INDONESIA
}

\author{
Aprista Ristyawati \\ Fakultas Hukum, Universitas Diponegoro \\ Jalan Prof. Soedarto, S.H., Tembalang, Semarang \\ aprista_r@yahoo.co.id
}

\begin{abstract}
The Corona Virus Disease (COVID - 19) is currently happening has increasingly troubled global public health. COVID-19 does not only affect the public health sector, but also many other sectors ranging from the economy, education, culture, politics, to government. Specifically in the political field, the COVID-19 pandemic has resulted in postponement of the 2020 regional elections (Pilkada). In this paper, we will discuss the negative impacts of continuing to hold the 2020 regional elections in the midst of the COVID-19 pandemic and how efforts can be achieved so that the 2020 simultaneous regional elections can be carried out well. This paper will be shown that the holding of simultaneous regional elections in 2020 has positive and negative impacts, but there are several efforts that can be achieved so that the 2020 regional elections can be carried out well.
\end{abstract}

Keywords : Simultaneous Regional Elections; COVID-19

\begin{abstract}
Abstrak
Wabah Corona Virus Disease (COVID - 19) yang terjadi saat ini semakin meresahkan kesehatan masyarakat global. COVID-19 tidak hanya berdampak terhadap sektor kesehatan publik, tetapi juga banyak sektor lain mulai dari ekonomi, pendidikan, budaya, sosial, politik, hingga pemerintahan. Secara khusus dalam bidang politik), pandemi COVID-19 telah mengakibatkan pemilihan kepala daerah (pilkada) 2020 mengalami penundaan. Pada tulisan ini, akan membahas mengenai dampak negatif dengan tetap diselenggarakannya pilkada serentak 2020 di tengah pandemi COVID-19 dan bagaimana upaya-upaya yang dapat ditempuh agar pilkada serentak 2020 dapat terlaksana dengan baik. Tulisan ini, dapat ditunjukkan bahwa tetap diselenggarakannya pilkada serentak tahun 2020 ini mempunyai dampak positif dan dampak negatif, namun ada beberapa upaya yang dapat ditempuh agar pilkada serentak tahun 2020 dapat terlaksana dengan baik.
\end{abstract}

Kata Kunci : Pilkada Serentak; COVID-19

\section{A. Pendahuluan}

Wabah Corona Virus Disease (COVID - 19) yang terjadi di seluruh negara di dunia saat ini semakin merajalela. Kasus pneumonia unknown etiology atau Covid-19 ini pertama kali terdeteksi di Kota Wuhan, Provinsi Hubei, Cina pada tanggal 31 Desember 2019. Sudah hampir sembilan bulan lamanya kasus Corona virus/ COVID-19 menjadi bencana nasional sejak bulan Maret 2020 lalu. Pandemi seperti ini juga telah mengakibatkan krisis tata kelola dan 
kebijakan penanganan pandemi di berbagai negara di dunia ${ }^{1}$. Indonesia sebagai negara hukum dalam menghadapi wabah pandemi COVID-19 melakukan upaya pencegahan terhadap jenis penyakit menular tersebut wajib dibentuk dalam sebuah aturan atau regulasi.

Banyak sektor dalam kehidupan manusia megalami dampak karena adanya wabah COVID-19. Tidak hanya sektor kesehatan publik saja yang mengalami dampak yang signifikan, tetapi juga banyak sektor lain mulai dari pendidikan, ekonomi, budaya, sosial, politik, hingga pemerintahan. Pada tahun 2020 ini, Indonesia memang akan melaksanakan pesta demokrasi yaitu pemilihan kepala daerah / pilkada serentak. Namun dengan wabah yang terjadi saat ini dan dengan semakin meningkatnya jumlah kasus covid-19 di Indonesia memang sangat berpengaruh kepada sector politik khususnya. Mengingat kasus covid-19 yang semakin merajalela maka pemerintah mengeluarkan kebijakan terkait penundaan pemilihan kepala daerah (pilkada) serentak tahun 2020. Indonesia memiliki agenda untuk menyelenggarakan Pemilihan Umum Kepala Daerah (Pilkada) di tanggal 23 September 2020. Namun, melalui Peraturan Pemerintah Pengganti Undang-Undang (Perpu) Nomor 2 Tahun 2020 tentang Perubahan Ketiga atas Undang-Undang Nomor 1 Tahun 2015 tentang Penetapan Peraturan Pemerintah Pengganti Undang-Undang Nomor 1 Tahun 2014 tentang Pemilihan Gubernur, Bupati, dan Walikota Menjadi Undang-Undang, Pemerintah Indonesia memutuskan untuk menjadwalkan ulang pilkada menjadi tanggal 9 Desember $2020^{2}$. Keputusan tersebut tentunya menimbulkan perdebatan di masyarakat. Menyikapi penundaan beberapa tahapan pilkada pada masa pandemic COVID-19 dapat menimbulkan berbagai dampak dalam penyelenggaraannya, baik yang sifatnya positif maupun negatif.

Terkait pelaksanaan pemilihan umum di beberapa negara, ada 55 negara menunda pemilu nasional ataupun lokal dan referendum nasional. Namun, ada 21 negara yang tidak menunda pemilu, 9 diantaranya telah terselenggara di tengah pandemi COVID-19. Korea Selatan menjadi salah satu negara yang berhasil menyelenggarakan pemilu pada 15 April 2020 (International Institute for Democracy and Electoral Assistance, 2020). Di Indonesia, penjadwalan pilkada serentak yang akan diselenggarakan di bulan Desember 2020 dinilai tak realistis. Karena faktanya, hingga menjelang bulan Desember 2020 ini jumlah kasus positif COVID-19 terus meningkat secara nasional. Banyak pihak khawatir, bila pilkada tetap dilangsungkan Desember 2020 justru akan menjadi klaster baru penyebaran COVID-19.

1 W. Mas'udi dan P.S. Winanti, 2020, Dari Krisis Kesehatan ke Krisis Tata Kelola. In W. Tata Kelola Penanganan COVID-19 di Indonesia Kajian Awal, Yogyakarta, Gadjah Mada University Press, hlm 315.

2 Peraturan Pemerintah Pengganti Undang-Undang (Perpu) Nomor 2 Tahun 2020 tentang Perubahan Ketiga atas Undang-Undang Nomor 1 Tahun 2015 tentang Penetapan Peraturan Pemerintah Pengganti Undang-Undang Nomor 1 Tahun 2014 tentang Pemilihan Gubernur, Bupati, dan Walikota Menjadi Undang-Undang 
Berdasarkan latar belakang tersebut, maka dapat dirumuskan permasalahan sebagai berikut pertama, apa dampak positif dan dampak negatif dengan tetap diselenggarakannya pilkada serentak 2020 di tengah pandemi COVID-19? dan kedua, bagaimana upaya-upaya yang dapat ditempuh agar pilkada serentak 2020 dapat terlaksana dengan baik?

\section{B. Pembahasan}

\section{Dampak Positif dan Dampak Negatif Tetap diselenggarakannya Pilkada Serentak 2020 di tengah pandemi COVID-19}

Pemilihan Umum / pemilu merupakan konsekuensi logis dari negara demokrasi, dan demokrasi adalah cara aman untuk mempertahankan kontrol atas negara hukum ${ }^{3}$. Pada Pasal 1 ayat (2) dan ayat (3) UUD NRI Tahun 1945 menjelaskan bahwa Indonesia adalah negara hukum yang demokratis. Demokratis berarti kedaulatan berada di tangan rakyat dan dilaksanakan menurut Undang-Undang Dasar. Demokrasi, negara hukum, dan negara kesejahteraan menjadi dasar filosofis dari penyelenggaraan pemilu ${ }^{4}$. Menurut Satjipto Rahardjo, Pemilu yang demokratis ialah lembaga yang mereproduksi kontrak sosial baru antara rakyat dengan pemimpin pemerintahan ${ }^{5}$. Sedangkan menurut Jimly Asshiddiqie, pemilu selain sebagai perwujudan demokrasi dan Hak Asasi Manusia (HAM), juga bertujuan untuk mengisi dan melaksanakan suksesi kepemimpinan secara tertib ${ }^{6}$. Dalam melaksanakan pemilihan umum yang demokratis, dapat dijalankan secara langsung maupun tidak langsung ${ }^{7}$.

Di tahun 2020 ini Indonesia memang akan melaksanakan pesta demokrasi yaitu dengan pemilihan umum kepala daerah secara serentak. Pemilihan Umum Kepala Daerah Serentak artinya Pemilihan kepala daerah yang dilakukan secara langsung oleh penduduk daerah administrative setempat yang memenuhi syarat, yang dilakukan secara bersamaan di daerahdaerah yang ada di Indonesia. Pemilihan kepala daerah dilakukan sekaligus bersama wakil kepala daerahnya, yang mana mencakup Gubernur dan Wakil Gubernur untuk provinsi, Bupati dan Wakil Bupati untuk kabupaten, dan Wali Kota dan Wakil Wali Kota untuk kota. Ada 270 wilayah di Indonesia akan menggelar Pilkada 2020. Pilkada serentak 2020 ini merupakan Pilkada serentak gelombang keempat yang dilakukan untuk kepala daerah hasil pemilihan

3 Arief Hidayat, 2010, Bernegara Itu Tidak Mudah (Dalam Perspektif Politik dan Hukum), Dalam Pidato Pengukuhan Guru Besar Ilmu Hukum, Semarang, Fakultas Hukum Universitas Diponegoro, hlm 32

4 Harry S Nugraha, "Gagasan Amandemen Ulang Undang-Undang Dasar Negara Republik Indonesia Tahun 1945", Jurnal Lex Renaissance, Vol. 3, (No. 1), 2018, hlm 61-85

5 Ida Budhiati, "Quo Vadis Demokrasi Prosedural dan Pemilu: Sebuah Refleksi Teoritis" Jurnal Masalah-Masalah Hukum, Vol. 42, (No. 2), 2013, hlm 268-273

6 Jimly Asshiddiqie, 2014, Pengantar IImu Hukum Tata Negara, Edisi 1, Cetakan 6, Jakarta, Rajawali Pers, hlm 17

7 W. Melfa, "Penataan Hukum Menuju Hukum Ideal Dalam Pengaturan Pemilukada", Masalah-Masalah Hukum, Vol. 42, (No. 2), 2013, hlm 211-217. 
Desember 2015. Ada 270 daerah yang melaksanakan pilkada serentak 2020, rinciannya adalah 9 provinsi, 224 kabupaten, dan 37 kota. Pilkada Serentak 2020 seharusnya diikuti 269 daerah, namun menjadi 270 karena Pilkada Kota Makassar diulang pelaksanaannya. ${ }^{8}$

Di tengah-tengah pandemi COVID-19 yang terjadi saat ini dan dengan tetap diselenggarakannya Pilkada serentak tahun 2020 yang awalnya dilaksanakan pada tanggal 23 September 2020 dan ditunda menjadi bulan Desember 2020 memang sudah seharusnya negara mampu merespon keadaan yang dimanifestasikan dalam wujud peraturan perundangan-undangan sebagai jaminan konstitutisonalitas penundaan Pilkada 2020. Peraturan tersebut harus mampu bertindak guna melindungi rakyat dan menjamin kesejahteraan sesuai dengan tujuan negara yang tercantum pada Pembukaan UUD NRI Tahun 1945.

Dengan tetap diselenggarakannya Pilkada Serentak 2020 di tengah pandemi COVID-19 ini dengan aturan yang berlaku tentunya memiliki dampak positif dan juga dampak negatif. Dampak positifnya antara lain :

\section{a. Amanat Regulasi yang berlaku tetap terlaksana}

Dengan diselenggarakannya Pilkada Serentak tahun 2020 berarti pula merupakan pelaksanaan amanat yang tertuang dalam Undang-Undang Nomor 10 Tahun 2016 Pasal 201 ayat 6 dapat terlaksana yang mana berbunyi "Pemungutan suara serentak Gubernur dan Wakil Gubernur, Bupati dan Wakil Bupati, serta Walikota dan Wakil Walikota hasil pemilihan tahun 2015 dilaksanakan pada bulan September tahun $2020 "$. Namun memang karena pandemi covid-19 ini pilkada serentak ditunda dengan dikeluarkannya Perpu Nomor 2 Tahun 2020 tentang Perubahan Ketiga Atas Undang-Undang Nomor 1 Tahun 2015 tentang Penetapan Peraturan Pemerintah Pengganti Undang-Undang Nomor 1 Tahun 2014 tentang Pemilihan Gubernur, Bupati, dan Walikota Menjadi Undang-Undang, yang mana terdapat pada Pasal 201A ayat (2) yaitu "Pemungutan suara serentak yang ditunda sebagaimana dimaksud pada ayat (I) dilaksanakan pada bulan Desember 2O2O", yang mana penundaan pilkada serentak ini tetap dilaksanakan di tahun yang sama yaitu bulan desember 2020.

Pilkada serentak ini memang harus tetap diselenggarakan namun tentunya dengan protokol Kesehatan yang ketat, karena peran dan posisi dari kepala daerah memang sangat dibutuhkan untuk saling bersinergi dan berkolaborasi dengan

8 “Ini 270 Daerah yang Gelar Pilkada Serentak 2020", Detiknews, Minggu 23 Juni 2019.

9 Pasal 201 ayat 6 Undang-Undang Nomor 10 Tahun 2016 tentang Perubahan Kedua Atas UndangUndang Nomor 1 Tahun 2015 tentang Penetapan Peraturan Pemerintah Pengganti Undang-Undang Nomor 1 Tahun 2014 tentang Pemilihan Gubernur, Bupati, dan Walikota menjadi Undang-Undang 
pemerintah pusat guna mempercepat penanganan COVID-19 serta percepatan proses pemulihan pasca-COVID-19.

\section{b. Hak Konstitusional Peserta Pilkada dan Masyarakat tetap terpenuhi}

Implementasi dari kedaulatan rakyat salah satunya ialah dengan diselenggarakannya pemilihan umum. Mengingat tahun 2020 ini Indonesia akan menyelenggarakan pilkada serentak, maka pilkada serentak ini harus tetap dilaksanakan walaupun berada ditengah-tengah wabah pandemi covid-19 namun tentunya juga tetap menerapkan protokol Kesehatan. Pilkada serentak ini merupakan salah satu sarana penyaluran hak asasi warga negara yang sangat principal, maka dari itu dalam rangka pelaksanaan hak-hak asasi warga negara sudah seharusnya pemerintah menjamin terlaksananya pilkada serentak tahun 2020 apalagi sudah seharusnya pula Pemerintah menjamin agar pelaksanaan pilkada serentak jangan sampai tertunda lebih lama lagi. Hal terkait Penyelenggaraan pemilu yang ada di dalam Undang Undang Dasar NRI Tahun 1945, merupakan salah satu dasar dari segala bentuk konstitusi bangsa Indonesia. Karena, momentum politik seperti pilkada merupakan suatu pengimplementasian hak konstitusional seluruh warga negara. Baik mereka sebagai calon peserta pemilu maupun siapa saja yang hendak menyalurkan hak politiknya untuk memilih dan dipilih.

\section{c. Mengurangi praktik kepemimpinan pemerintah daerah yang terlalu banyak dipimpin oleh pejabat sementara}

Kewenangan yang dimiliki oleh Pejabat sementara atau pelaksana tugas (PIt) sangat terbatas. Hal tersebut tidak memungkinkan mereka dapat mengambil kebijakan yang strategis. Artinya para pejabat sementara tidak dapat mempunyai wewenang untuk membuat aturan yang mana sangat penting sekali diberlakukannya aturan yang dapat menyelesaikan persoalan di masa pandemic COVID-19 ini dan juga dianggap kurang efektif karena kewenangan yang dimiliki oleh Pejabat sementara sangat terbatas, sehingga akan memperlambat kinerja.

Kepala Daerah dan wakil kepala daerah Bukan sekadar simbol pemerintahan, tapi gubernur, wali kota atau bupati memiliki kewenangan yang lebih powerful, misalnya dalam bidang penataan organisasi birokrasi, SDM atau kepegawaian maupun soal alokasi anggaran untuk merealisasikan janji-janji kampanyenya pada rakyat yang telah memilihnya. 


\section{d. Mencegah Pembengkakan Anggaran}

Dampak lain yang perlu dipikirkan lagi jika pelaksanaan pilkada tahun 2020 ini ditunda adalah pembengkakan biaya. Pembengkakan biaya yang dimaksud yaitu baik dari pemerintah maupun dari pasangan-pasangan calon kepala daerah yang mana sudah banyak mengeluarkan biaya operasional dalam melalukan sosialisasi dan persiapan lainnya guna keperluan pilkada. Anggaran yang telah dicairkan pada tahun 2020 akan terbuang sia-sia karena lewat tahun anggaran.

Dampak positif tersebut akan terwujud apabila penyelenggaraan pilkada serentak 2020 ini dilakukan dengan tetap menerapkan protokol Kesehatan secara ketat dan baik. Selain dampak positif, dengan diselenggarakannya pilkada juga membuat kekhawatiran sehingga ada potensi menimbulkan dampak negatif, antara lain :

\section{a. Risiko Penularan COVID-19 Semakin Tinggi}

Dengan tetap diselenggarakannya Pilkada ini memang tidak dapat dipungkiri sangat berpotensi memunculkan kerumunan-kerumunan massa yang mana potensi penularan sangat tinggi. Pilkada di masa pandemi punya risiko besar. Seperti tecermin pada hari pertama pendaftaran pasangan calon pada tanggal 4 September lalu, banyak pasangan calon di berbagai daerah memancing kerumunan dengan melakukan konvoi yang kebanyakan tidak memperhatikan protokol Kesehatan covid19. Terlebih lagi, kini sejumlah bakal calon juga terinfeksi virus Corona. Hal tersebut tentunya sangat membuat semakin resah apalagi nanti pada saat menjelang pilkada dilaksanakan, yang ditakutkan lonjakan kasus covid-19 bisa menciptakan krisis yang semakin meresahkan semua masyarakat. Hal tersebut tentu sangat berpotensi menciptakan klaster besar apalagi di daerah-daerah yang sebelumnya masih berkategori zona hijau bisa jadi dengan diselenggarakannya pilkada bisa berpotensi menjadikan daerah tersebut zona merah jika semua orang tidak memiliki kesadaran untuk tetap melaksanakan protokol Kesehatan covid-19.

\section{b. Berpotensi adanya praktik kecurangan yang semakin rawan}

Dengan tetap diselenggarakannya pilkada tahun 2020 tentunya akan membuat kekhawatiran terhadap potensi terjadinya praktik kecurangan. Sebagai contoh adanya potensi politik uang yang semakin marak di tengah kondisi pandemi. Perekonomian yang melemah berdampak banyak warga yang mengalami kesulitan untuk memenuhi kebutuhan hidup. Hal tersebut ditakutkan para pemilih memilih calon kepala daerah 
tanpa mempertimbangkan kualitas yang baik hanya karena diiming-imingi uang saja yang bahkan jumlahnya pun tidak seberapa.

Selain itu, potensi pelanggaran pada hari pelaksanaan pilkada serentak tahun 2020 ini dapat berpotensi terjadi pada tiga tahapan pilkada, yaitu pada tahapan pemungutan, penghitungan dan rekapitulasi. Terutama pada tahapan rekapitulasi adalah pembukaan kotak suara di luar ketentuan, pemungutan di tengah pandemi covid ini menggunakan hal baru di dalam hal penggunaan teknologi dan ditakutkan adanya penyalahgunaan dalam penggunaan teknologi tersebut.

\section{c. Penolakan Pilkada Berpotensi Meningkatkan Angka Golput}

Keputusan pemerintah terkait penyelenggaraan Pilkada mendapatkan protes oleh beberapa masyarakat. Dikhawatirkan dengan tetap dilaksanakannya Pilkada serentak tahun 2020 ini diprediksi akan berpotensi memunculkan masyarakat yang tidak menggunakan hak pilihnya dengan bijak atau biasa disebut dengan istilah Golput (Golongan Putih) karena alasan kesehatan dan keselamatan warga.

Menjadi Golput boleh jadi adalah pilihan yang paling rasional mengingat kesehatan dan keselamatan publik tengah terancam di tengah situasi wabah covid-19 yang sangat membuat resah. Hal yang ditakutkan adalah jika pemerintah tetap menerapkan kebijakannya untuk tetap menyelenggarakan pilkada serentak yang berpotensi memiliki risiko akan membuat kepercayaan publik terhadap negara akan menurun. Apalagi situasi yang ada saat ini diperparah dengan maraknya spekulasi tentang kolusi dan menguatnya politik dinasti di kalangan pemerintah serta maraknya politik uang karena perekonomian Indonesia yang semakin terpuruk sehingga Pilkada yang bersih dan jujur sulit untuk diselenggarakan.

\section{Upaya-Upaya Agar Pilkada Serentak 2020 Dapat Terlaksana Dengan Baik}

Dengan tetap diselenggarakannya pilkada serentak tahun 2020 di tengah-tengah pandemi COVID-19 yang masih mewabah di Indonesia ini tentunya kita semua berharap, baik dari aspek demokrasi maupun kesehatan masyarakat, sama-sama dapat tercapai dan tidak ada satupun yang dipertaruhkan. Pesta demokrasi yang terwujud melalui pilkada serentak tahun 2020 diharapkan dapat berjalan dengan lancar, tingkat partisipasi masyarakat tetap tinggi, sekaligus masyarakat juga tetap aman dari COVID-19. Maka dari itu dilakukan beberapa upaya agar pilkada serentak tahun 2020 ini dapat berjalan dengan baik dan efektif. Upaya-upaya tersebut antara lain : 


\section{a. Meningkatkan Pengawasan Protokol Kesehatan}

Upaya dalam persiapan pelaksanaan pilkada serentak tahun 2020 yang baik tentu dapat meningkatkan kualitas berdemokrasi dengan tetap patuh protokol kesehatan untuk mencegah penularan Covid-19. Pada tiap tahapan pilkada diharapkan semua dapat menyesuaikan dengan mekanisme pemilihan dan protokol kesehatan Covid-19.

Penyelenggara Pilkada, para kepala daerah dan para calon kepala daerah, pengawas Pilkada, serta aparat keamanan negara diharapkan juga agar turut berperan aktif dalam menciptakan situasi yang kondusif dalam pelaksanaan Pilkada Serentak 2020 pada 9 Desember 2020 nanti.

Salah satu upaya agar pilkada serentak tahun 2020 tetap terlaksana adalah dengan menerapkan aturan pada Pasal 11 Peraturan Komisi Pemilihan Umum Republik Indonesia Nomor 6 Tahun 2020 tentang Pelaksanaan Pemilihan Gubernur dan Wakil Gubernur, Bupati dan Wakil Bupati, dan/atau Wali Kota dan Wakil Wali Kota Serentak Lanjutan dalam Kondisi Bencana Nonalam Corona Virus Disease 2019 (COVID-19) : ${ }^{10}$

(1) Setiap Penyelenggara Pemilihan, Pasangan Calon, Tim Kampanye, Penghubung Pasangan Calon, serta para pihak yang terlibat dalam Pemilihan Serentak Lanjutan wajib melaksanakan protokol kesehatan pencegahan dan pengendalian Corona Virus Disease 2019 (COVID-19) sebagaimana dimaksud dalam Pasal 5 sampai dengan Pasal 9 paling kurang berupa penggunaan masker yang menutupi hidung dan mulut hingga dagu.

(2) Dalam hal terdapat pihak yang melanggar kewajiban sebagaimana dimaksud pada ayat (1), KPU Provinsi, KPU Kabupaten/Kota, PPK, atau PPS memberikan teguran kepada pihak yang bersangkutan untuk mengikuti ketentuan protokol kesehatan pencegahan dan pengendalian Corona Virus Disease 2019 (COVID19).

(3) Dalam hal pihak yang bersangkutan telah diberikan teguran sebagaimana dimaksud pada ayat (2) tetap tidak melaksanakan protokol kesehatan protokol kesehatan pencegahan dan pengendalian Corona Virus Disease 2019 (COVID19), KPU Provinsi, KPU Kabupaten/Kota, PPK, atau PPS berkoordinasi dengan Bawaslu Provinsi, Bawaslu Kabupaten/Kota, Panwaslu Kecamatan, atau

10 Pasal 11 Peraturan Komisi Pemilihan Umum Republik Indonesia Nomor 6 Tahun 2020 tentang Pelaksanaan Pemilihan Gubernur dan Wakil Gubernur, Bupati dan Wakil Bupati, dan.atau Wali Kota dan Wakil Wali Kota Serentak Lanjutan dalam Kondisi Bencana Nonalam Corona Virus Disease 2019 (COVID-19) 
Panwaslu Kelurahan/Desa untuk mengenakan sanksi sesuai dengan ketentuan peraturan perundang- undangan.

\section{b. Tetap menjunjung integritas dalam Penyelenggaran Pilkada}

Integritas merupakan suatu keutamaan, suatu karakter baik manusia atau budaya baik organisasi, yang menimbulkan daya dorong bagi pemiliknya untuk mewujudkan keputusan dan tindakan bagi kebaikan bersama ${ }^{11}$. Integritas sangat berperan dalam mengarahkan kompetensi untuk menghasilkan kinerja baik dan berkualitas. Dalam penyelenggaraan pilkada, integritas dapat dilihat dari semua sisi subyek. Dari sisi penyelenggara pilkada, dapat dilihat seberapa konsistennya dalam melaksanakan hukum dan aturan pemilihan kepala daerah. Dari sisi peserta pilkada, dapat dilihat dari bagaimana wujud pelaksanaan hukum penyelenggaraan pilkada dan apakah mencari celah untuk melakukan pelanggaran serta setelah memenangkan suara dalam pilkada akan menepati janji dan menerapkan program dan kebijakannya atau tidak. Dari sisi pemilih, dapat dilihat dari bagaimana ikut serta dalam mengawasi pelaksanaan pilkada sebelum maupun sesudahnya serta dilihat dari bagaimana pemilih tidak ikut menjadi pelanggar pilkada.

Dalam menerapkan integritas ada beberapa tantangan yang menjadi faktor yang melemahkan integritas, antara lain ${ }^{12}$ : (1) Rendahnya nilai religiusitas, disiplin serta etika dalam bekerja serta adanya sifat tamak, egois dan mementingkan diri sendiri; (2) Tidak adanya good will serta keteladanan dari pemimpin untuk meningkatkan integritas. Karena Keputusan pemimpin yang berlawanan dengan ketentuan perundang-undangan tentunya dapat menyebabkan runtuhnya integritas tersebut; (3) Sistem dan prosedur yang tidak transparan dan efektif, hal tersebut ditakutkan berpotensi terjadinya kecurangan dalam hal ini adalah kecurangan dalam pelaksanaan pilkada yang mana hak tersebut juga dapat dikategorikan menciderai demokrasi; (4) Struktur organisasi yang tidak sistematis, tidak memiliki tujuan yang jelas, tumpang tindih pembagian tugas dan adanya persaingan yang tidak sehat; (5) Budaya kerja yang tidak mementingkan integritas.

11 Gunardi Endro, "Menyelisik Makna Integritas dan Pertentangannya dengan Korupsi”, Universitas Bakrie, Volume 3, Nomor 1, Maret 2017 , hlm 131.

12 Agni Indriani, "Mewujudkan Penyelenggara Pemilu Berintegritas, Suara KPU Jawa Timur", Jurnal Inspirasi Demokrasi, November 2016, hlm 13. 


\section{c. Harus ada komitmen baik untuk Peserta pilkada maupun pelaksana}

Penegakan disiplin protokol kesehatan sangat diutamakan mengingat aktivitas pilkada terutama kampanye adalah tahap yang melibatkan massa. Hal ini merupakan tantangan yang besar dalam rangka melaksanakan pilkada serentak tahun 2020 di tengah pandemi COVID-19 ini. Karena beberapa pelanggaran mengenai penegakan disiplin protokol Kesehatan masih banyak terjadi. Perlu disadari bahwa dalam pelaksanaan pilkada serentak ini tidak hanya menyangkut persaingan politik antar calon, namun juga menyangkut antara politik dengan Kesehatan.

\section{d. Kedisiplinan Masyarakat}

Rencana pilkada tidak boleh mengabaikan kesehatan dan keamanan masyarakat, yang jauh lebih penting. Tidak mungkin mempertaruhkan kesehatan dan keselamatan masyarakat atas nama demokrasi. Demokrasi itu sendiri sejatinya adalah untuk kebaikan dan kesejahteraan masyarakat. Demokrasi memiliki makna pemerintahan dari rakyat, oleh rakyat, dan untuk rakyat. Artinya, setiap kebijakan apapun itu adalah untuk kebaikan dan kemaslahatan masyarakat. Pelaksanaan demokrasi itu penting, tetapi kesehatan dan keamanan masyarakat juga penting.

Badan Pengawas Pemilu RI telah gencar mengingatkan protokol kesehatan pencegahan COVID-19 dalam Pilkada 2020. Apabila ada pihak yang terlibat dalam pilkada kemudian tidak mematuhi protokol kesehatan maka siap-siap mendapatkan teguran hingga sanksi. Oleh karena itu tantangan tersebut harus kita cegah dengan cara bersama-sama baik penyelenggara Pilkada, pemerintah, partai politik pasangan calon, masyarakat bagaimana kita punya komitmen punya niat yang kuat untuk menyelenggarakan pilkada dalam situasi COVID dengan baik dan tetap aman.

\section{Simpulan}

Berdasarkan pembahasan tersebut, maka dapat disimpulkan bahwa tetap terselenggaranya Pilkada Serentak tahun 2020 di tengah pandemi COVID-19 memiliki dampak positif dan juga dampak negatif. Dampak positifnya antara lain amanat regulasi yang berlaku tetap terlaksana, hak konstitusional peserta Pilkada dan masyarakat tetap terpenuhi, mengurangi praktik kepemimpinan pemerintah daerah yang terlalu banyak dipimpin oleh pejabat sementara, mencegah pembengkakan anggaran. Sedangkan dampak negatifnya antara lain resiko penularan COVID-19 semakin tinggi, berpotensi adanya praktik kecurangan yang semakin rawan, penolakan Pilkada berpotensi meningkatkan angka golput. Upaya-upaya agar Pilkada serentak 2020 dapat terlaksana dengan baik antara lain meningkatkan 
pengawasan protokol kesehatan, tetap menjunjung integritas dalam penyelenggaraan Pilkada, harus ada komitmen baik untuk peserta Pilkada maupun pelaksana, kedisiplinan masyarakat.

\section{DAFTAR PUSTAKA}

\section{Buku:}

Asshiddiqie,Jimly, 2014, Pengantar Ilmu Hukum Tata Negara, Edisi 1, Cetakan 6, Jakarta, Rajawali Pers.

Dahl, Robert A., 1971, Polyarchy: Opposition and Participation, Yale University Press, New Haven and London.

W.Mas'udi \& Winanti, P. S, 2020, Dari Krisis Kesehatan ke Krisis Tata Kelola. In W. Tata Kelola Penanganan COVID-19 di Indonesia Kajian Awal, Yogyakarta, Gadjah Mada University Press.

\section{Jurnal:}

Akbar,Idil, 2016, Pilkada Serentak dan Geliat DInamika Politik dan Pemerintahan Lokal Indonesia, Jurnal IImu Pemerintahan, Vol.2. No.1 April 2016

Budhiati Ida, 2013, "Quo Vadis Demokrasi Prosedural dan Pemilu: Sebuah Refleksi Teoritis" Jurnal Masalah-Masalah Hukum, Vol. 42, (No. 2).

Endro , Gunardi, 2017, "Menyelisik Makna Integritas dan Pertentangannya dengan Korupsi", Universitas Bakrie, Volume 3, Nomor 1

Indriani, Agni, 2016, "Suara KPU Jawa Timur”, Jurnal Inspirasi Demokrasi, November 2016.

Melfa, W, 2013, "Penataan Hukum Menuju Hukum Ideal Dalam Pengaturan Pemilukada", Jurnal Program Studi Magister Ilmu Hukum Fakultas Hukum Universitas Diponegoro Masalah-Masalah Hukum, Vol. 42, (No. 2)

Nugraha, Harry S, 2018, "Gagasan Amandemen Ulang Undang-Undang Dasar Negara Republik Indonesia Tahun 1945", Jurnal Lex Renaissance, Vol. 3, (No. 1)

\section{Orasi IImiah:}

Hidayat, Arief, 2010, "Bernegara Itu Tidak Mudah (Dalam Perspektif Politik dan Hukum)", Dalam Pidato Pengukuhan Guru Besar Ilmu Hukum, Semarang, Fakultas Hukum Universitas Diponegoro,

\section{Surat Kabar:}

“Ini 270 Daerah yang Gelar Pilkada Serentak 2020”, Detiknews, Minggu 23 Juni 2019. 


\section{Peraturan Perundang-undangan:}

Undang-Undang Nomor 10 Tahun 2016 tentang Perubahan Kedua Atas Undang-Undang Nomor 1 Tahun 2015 tentang Penetapan Peraturan Pemerintah Pengganti UndangUndang Nomor 1 Tahun 2014 tentang Pemilihan Gubernur, Bupati, dan Walikota menjadi Undang-Undang

Peraturan Komisi Pemilihan Umum Republik Indonesia Nomor 6 Tahun 2020 tentang Pelaksanaan Pemilihan Gubernur dan Wakil Gubernur, Bupati dan Wakil Bupati, dan.atau Wali Kota dan Wakil Wali Kota Serentak Lanjutan dalam Kondisi Bencana Nonalam Corona Virus Disease 2019 (COVID-19)

Peraturan Pemerintah Pengganti Undang-Undang (Perpu) Nomor 2 Tahun 2020 tentang Perubahan Ketiga atas Undang-Undang Nomor 1 Tahun 2015 tentang Penetapan Peraturan Pemerintah Pengganti Undang-Undang Nomor 1 Tahun 2014 tentang Pemilihan Gubernur, Bupati, dan Walikota Menjadi Undang-Undang 